\title{
The Teacher as a Lesson Designer
}

LJERKA JUKIĆ MATIĆ ${ }^{1}$

$\approx$ Teachers' pedagogical design capacity is their ability to perceive and mobilise existing resources to create productive instructional episodes in the classroom. To a certain extent, this ability is dependent on the curricular resource used. As the textbook remains the most commonly used curricular resource in mathematics classrooms, the study reported in this paper investigates how and why one experienced mathematics teacher utilises the textbook. Data were gathered using lesson observations, as well as pre-lesson and post-lesson interviews. The teacher used offloading on the textbook, adapting the textbook content and improvising in the lessons to varying degrees, being aware of the affordances and constraints that the textbook has for her teaching practice. That approach to the textbook enabled the teacher to create various opportunities that enhance learning. The results of the study indicate that the mathematics teacher's awareness of what a particular resource offers for teaching practice, and what constraints could be encountered on this journey are significant in terms of the teacher's design capacity.

Keywords: mathematics teacher, pedagogical design capacity, curriculum resources, teaching/learning process, teaching/learning mathematics 


\section{Učitelj kot oblikovalec učnih ur}

LJERKA JUKić Matić

$\propto$ Pedagoška sposobnost učiteljev, da prepoznajo in uporabijo obstoječe vire $\mathrm{z}$ namenom oblikovanja produktivnih učnih enot, se odraža $\mathrm{v}$ njihovi splošni sposobnosti učinkovitega načrtovanja pouka. Ta je do določene mere odvisna od uporabljenega kurikularnega vira. Ker je učbenik pri pouku matematike še vedno najpogosteje uporabljen kurikularni vir, je namen opisane raziskave preučevanje načina in vzroka rabe učbenika izkušene učiteljice matematike. Podatki so bili pridobljeni z opazovanjem pouka ter intervjuji pred poukom in po njem. Učiteljica je uporabila posamezne lekcije iz učbenika, prilagodila njihovo vsebino in $\mathrm{v}$ različnem obsegu $\mathrm{v}$ razredu improvizirala učenje, pri čemer se je zavedala dostopnosti in omejitev učbenika $\mathrm{v}$ svoji pedagoški praksi. Tak pristop $\mathrm{k}$ učbeniku je učiteljici omogočil ustvarjanje raznovrstnih priložnosti za izboljšanje učenja. Izsledki raziskave kažejo, da zavedanje učiteljice matematike o številnih možnostih uporabe različnih virov in njihovih omejitev pri poučevanju pomembno vpliva na njeno sposobnost oblikovanja učnih ur.

Ključne besede: učitelj matematike, pedagoška sposobnost načrtovanja, kurikularni viri, proces poučevanja/učenja, poučevanje/ učenje matematike 


\section{Introduction}

For many decades, textbooks have been the main curriculum resources used in mathematics classrooms (Valverde et al., 2002) and this remains the case in most classrooms throughout the world (Fan, Zhu, \& Miao, 2013). Many mathematics teachers use the official textbook when planning and implementing their mathematics programmes (e.g., Thomson \& Fleming, 2004). Studies have found that many teachers prepare their lessons according to the textbook (e.g., Fan et al. 2013; Pepin \& Haggarty, 2001; Pepin, Gueudet, \& Trouche, 2013). Further, they showed that teachers relied on the textbook for teaching new content to a great extent, using the proposed pedagogy and the same language as given in the textbook and reproducing similar solved examples on the board (e.g., Pepin \& Haggarty, 2001). The practice exercises, which constitute an essential part of students' activity, were also assigned from the textbook, as was homework (e.g., Johansson, 2006; Pepin \& Haggarty, 2001).

Previously, curriculum developers and reformers relied on the idea that one can improve teaching only by using quality resources developed by experts, and the teachers would use those resources as intended by the developers (Clandinin \& Connelly, 1992). They ignored the role of the teacher and his influence on the teaching practice, which gave the teacher only a mediatory role; teachers were seen merely as conduits or mediators of the curriculum to students (e.g., Love \& Pimm, 1996). However, in recent years, there has been a shift in the perception of the teacher's position within the curriculum setting: from simply a mediator between the curriculum and students to a designer of curriculum instructions (Brown, 2009; Remillard, 2005). 'Teaching as design' means the teacher and curriculum resources participate in a dynamic and collaborative relationship, interacting with and influencing each other (Pepin, 2015). During lesson planning, teachers work with curricular resources: they interpret them and transform them as they design instruction. This interpretation and design of resources continue in lesson enactment (Pepin et al., 2013). Within this new perspective, in which the teacher is a designer of teaching, there are many unknowns including how textbooks can constrain or support teacher practice. This paper attempts to partly fill this gap, investigating how one lower-secondary mathematics teacher utilises the mathematics textbook as a curriculum resource to craft instruction. 


\section{Theoretical grounding}

The textbooks and curricular resources teachers engage with while planning mathematics instruction can be viewed as artefacts (Shield \& Dole, 2012), which are defined as outcomes of human activity, created with a precise aim of accomplishing a particular task (Rabardel, 2002; Wartofsky, 1979). As teachers use, shape, and form these artefacts to prepare for their teaching, they establish a particular relationship with the curricular resources. This relationship is a participatory one, in which both the characteristics of the teacher and the characteristics of the resources influence the outcomes in classroom practice (Brown, 2009; Remillard, 2005).

Brown (2009) calls a teacher's capacity to perceive and mobilise existing resources to create productive instructional episodes 'pedagogical design capacity' (PDC). Brown describes a teacher's PDC as a particular design skill that the teacher enacts to put various pieces into play. It characterises a process in which resources such as subject matter knowledge and pedagogical content knowledge are mobilised. Hence PDC is not just about the teacher's knowledge or goals, but about their ability to apply knowledge in new situations (Ball \& Cohen, 1999). Perceiving can be regarded as a teacher's act of recognising and interpreting existing resources, evaluating limitations of the classroom setting, and balancing trade-offs (Brown \& Edelson, 2003), while Remillard (2005) describes it as a teacher's ability to recognise and observe the potential of resources. In contrast, mobilising emphasises a teacher's enactment to devise strategies and act on or with the resources (Brown \& Edelson, 2003). Perceiving and mobilising curricular resources occur both during the lesson planning and enactment.

In the context of mathematics education, Pepin (2015) refers to a mathematics teacher's PDC as a mathematics-didactical design capacity. Gueudet, Pepin, and Trouche (2013) point out that a teacher's pedagogical design capacity is dependent on the used resource to some extent, and on the ways of working with the resource, because each resource has different affordances and constraints. Choppin (2011) connects PDC with learned adaptations, which are knowledge-based adaptations designed with respect to what teachers have learned from prior enactments. In other words, a teacher designs lessons on the basis of his knowledge from prior experience of how curriculum resources can be used to achieve particular outcomes.

To describe how teachers perceive and mobilise resources to design lessons, Brown (2009) coined the terms offloading, adapting, and improvising for different types of curriculum usage. While planning a lesson, teachers often 
adopt, adapt, modify, or omit curricular recommendations before they finalise the decisions on what they will teach and how they will perform this teaching (Brown, 2009). In this process, teachers' utilisation of resources happens at varying 'degrees of artefact appropriation' (Brown, 2009, p. 24). Offloading denotes relying mostly on the curriculum resources for the delivery of the lesson and giving agency to the materials for guiding instruction. Adapting indicates an equally-shared responsibility for the delivery of the lesson between teacher and curriculum resources; it occurs when teachers modify their materials to support instructional goals. Improvising occurs when teachers craft instruction spontaneously and without specific guidance from their materials, thus shifting agency to themselves. Here, the teacher relies mostly on external and their own resources for delivering the lesson. Therefore, from the perspective of textbook utilisation, teachers' development of PDC is an essential and critical part of their interactions with the textbook.

\section{Framework for examining teacher's work with the textbook}

Leshota (2015) proposed a framework for examining a teacher's work with a particular curriculum resource, i.e., textbook, and teacher's pedagogical design capacity (PDC). The framework examines the mobilisation of textbook content, the teacher's textbook utilisation, the teacher-textbook relationship and consequently delineates teacher's PDC.

The mobilisation of content is determined through the degree of appropriation and opportunities of mediation. The degree of appropriation shows how the teacher offloads, adapts or improvises in the lessons. Opportunities for mediation are examined through injections of mathematical content, omissions of mathematical content, and mathematical errors. Together, these indicators show the extent to which a teacher's mobilisation of the textbook content creates 'opportunities for mediation in the classroom, thus illuminating elements of teachers' PDC' (Leshota, 2015, p. 117).

Offloading, adapting and improvising are described in the previous section; injections and omissions will be elaborated on below. Leshota (ibid.) distinguishes between two types of injections: robust injections and distractive injections. Robust injections of mathematical content are those that enhance opportunities for learning mathematics. They point to the teacher's capacity to perceive what the textbook affords and also what the textbook constrains in the teaching practice. Distractive injections are injections of irrelevant mathematical content that detract from opportunities of learning. This relates to 
injections of content that can diverge from the common objectives of teaching and learning the topic, and lead to the introduction of mathematical errors. These injections display a teacher's lack of PDC. There is a difference between improvisations of content brought from other sources to lessons and injections of mathematical content. The category of injection of mathematical content deals with the content that was, regardless, not required by the relevant grade level but which the teacher brought to his/her lessons.

Leshota (ibid.) characterised omissions of mathematical content as productive omissions and critical omissions. Productive omissions do not detract from the opportunities of learning. They relate to leaving out similar examples or practice exercises from the textbook when assigning classroom activity, and they are ineffectual in the teacher-textbook relationship. Critical omissions of content are critical for students' learning of mathematics. They display the teachers' lack of PDC.

Regarding textbook utilisation, Leshota (2015) used the terms 'deliberate textbook use' and 'tacit use'. She described deliberate use as intentional, purposeful, conscious utilisation, characterised by engaging in long and careful considerations. Tacit textbook use referred to a teacher's use of the textbook that is not deliberate, characterised by distractive injections, and critical omissions. However, I will identify textbook utilisation as either deliberate or nondeliberate. Deliberate use will denote the teacher's intentional decision/action, based upon thoughtful considerations, and thus with explicit pedagogical rationale. In this way, I wanted to avoid the possible indirect implication that deliberate use could imply that the teacher's interventions are necessarily pedagogically beneficial (e.g., injections are robust, and omissions are productive). The deliberate, reflective approach far more often leads to beneficial outcomes, but these two dimensions are not necessarily connected. A teacher can deliberately design something to enhance students' learning, but after the classroom experience conclude that it was not productive.

Lastly, by summarising previous evaluations, one can determine the teacher-textbook relationship. Leshota (ibid) used the terms 'intimate' and 'non-intimate relationship'. In essence, she described the intimate relationship as a participatory relationship. However, in this study, the terms the 'participatory' and 'non-participatory relationship' will be used as more appropriate to describe this relationship. The participatory relationship comprises reflective (deliberate) decisions on 'distribution of design responsibility' i.e., the correct mixture of offloading, adapting, and improvising to enhance students' learning. 


\section{Research focus}

The large-scale study reported by Glasnović Gracin (2011) investigated nearly one thousand Croatian mathematics teachers on the utilisation of mathematics textbooks in lower secondary education in Croatia (Grades 5 to 8). The teachers were examined using a questionnaire with a modified Likert scale with four degrees: never, seldom, often, and almost always. The results showed that teachers use textbooks to a great extent for various activities (lesson preparation, teaching a new topic, exercises and assigning homework) and that textbooks were used more than other curriculum resources. Approximately 52\% of surveyed teachers claimed they almost always use the textbook for lesson preparation and an additional $45 \%$ do so often; $97 \%$ confirmed that they use the textbook as a source of mathematics exercises ( $51 \%$ almost always and $46 \%$ often); 99\% of participants stated that they use textbooks for giving homework (74\% almost always and a further $25 \%$ often). The results showed a strong reliance on the officially approved textbooks in Croatian mathematics education. As an extension of the large-scale quantitative study, Glasnović Gracin and Jukić Matić (2016) investigated the use of textbooks with 12 lower secondary mathematics teachers. This qualitative study involved on-site observations and interviews with the goal of determining whether teachers' self-reports on textbook utilisation differ from the actual situation in the classroom. The findings showed that the textbook played a central role in teachers' lesson preparation, as well as in the selection of solved examples and practice exercises for the students.

Glasnović Gracin (2011) also analysed Croatian mathematics textbooks. The results of the analysis point to the predominance of operation activities on the reproductive or simple-connections level with intra-mathematical content (i.e., symbolic exercises without context). The results showed that Croatian textbooks place more emphasis on algorithms and the view of mathematics as a tool rather than as a medium of communication. The analysis also showed that the requirements of the intended curriculum match the ones in the textbooks;

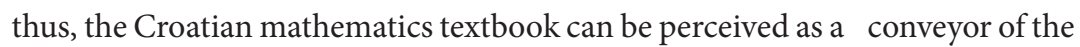
curriculum' (Fan et al., 2013, p. 635).

Although previous studies on Croatian teachers, as well as other aforementioned international studies, have shown that teachers rely on the textbook to a great extent for lesson planning and lesson implementation, they neglected the design component. Therefore, the research questions in this study are: How does an experienced teacher design a lesson utilising the textbook, particularly: 1) How does the teacher appropriate/mobilise the textbook for/in teaching and why? 
2) What can be inferred from the teacher's relationship with the textbook about the teacher's PDC?

\section{Method}

\section{The participants and data collection}

The study presented in this paper is a case study. The participant is a female mathematics teacher, Ms D, engaged in lower secondary education in Croatia (Grades 5 to 8 ) who was selected on the basis of personal acquaintance. Several in-service teachers, who mentor pre-service mathematics teachers, were approached to participate in the study, but they all declined, except for Ms D; therefore, the sample is purposeful (Patton, 2002). Ms D has two decades of teaching experience and, as an experienced and knowledgeable teacher, she represents a valuable participant for the study of textbook utilisation. She has been using the same textbook series for ten years. That mathematics textbook series is used by more than $65 \%$ of lower secondary students in Croatia (data retrieved from the Ministry of Education, Science, and Sport). The teacher was not acquainted with the objective of the research, thus preventing any significant changes in her teaching practice.

The data were collected in 2016 using on-site lesson observations and interviews to obtain an in-depth and extensive understanding of the researched issues. Lessons in Croatian schools last 45 minutes; therefore, the lessons were chunked into five-minute intervals. Each activity that took place in the classroom was recorded in the observational table and described in detail. Prior to each observation, the textbook content was examined, which helped in the initial coding during the observation: if the teacher offloaded, adapted, or improvised with the textbook content. The lessons were audio-recorded, which helped in catching the teacher's remarks and comments to students, and in the process of data analysis to connect the teacher's actions in the lesson with the pedagogical design capacity.

The teacher was interviewed before and after each lesson. Each prelesson interview focused on the specifics of the forthcoming lessons: to explain how she prepared for the lesson and to explain her lesson plan: what she used from the textbook and why; what she modified from the textbook and why; what she improvised using her personal resources and why; whether she omitted any content from the textbook or injected some mathematical content and why. Each pre-lesson interview lasted about 40 minutes. Additionally, the teacher participated in post-lesson interviews in which she was asked to 
evaluate the lesson, to reflect on the lesson outcomes, and to explain if and why the enacted lesson deviated from the planned lesson. Each post-lesson interview lasted about 20 minutes.

One of the weaknesses of the case study is its focus on depth, and not allowing people to generalise findings. Instead of generalisability, Goetz and Le Compte (1984) use the notion of 'translatability', i.e., a clear description of one's theoretical stance and research techniques, and the notion of 'comparability', i.e., whether the results of the study can be used as a basis for comparison. In this kind of research, 'thick descriptions' are thus vital for others to be able to determine if the attributes compared are relevant (Kvale, 1996). Therefore, I provided a good amount of detail about the study.

\section{Data analysis}

To examine how the teacher mobilises the textbook and whether the teacher has pedagogical design capacity, this study used the analytical framework created by Leshota (2015), described in a previous section.

To establish whether the teacher offloaded, adapted, or improvised in the lesson, the data from the observation table were compared with the data obtained from the pre-lesson interviews, and then with the textbook content to verify the obtained conclusions. Then content omitted from the textbook was analysed as to whether it was productive or critical. Injections of content were also analysed, and compared with the curriculum programme. Although the teacher provided an explanation or rationale for the omissions and injections, and therefore proposed initial categorisation, I made the main categorisation of omissions and injections based on my background as a mathematician and mathematics educator. Further, I relied to some extent on the analysis of Croatian mathematics textbooks made by Glasnović Gracin (2011), described in the previous section. The results of the analysis of teacher's mobilisation of the textbook content can be seen in Figure 2.

The next step in the data analysis was reviewing the pre-lesson interviews and coding the teacher's explanations in the lesson planning. In the first phase, the data were read to detect the processes behind the teacher's decision to offload, adapt, or improvise. In the second phase, the codes analysing, evaluating, adopting, adapting, creating, and learning adaptations were assigned where appropriate. For instance, for the introduction of rational numbers, Ms D decided not to use the suggestion from the textbook, because she found the pedagogy behind it to be inadequate after analysing the content and evaluating it in terms of her students (Figure 1). 
Their [in the textbook] pedagogy is completely wrong, for instance: they write $-\frac{8}{9}=8:(-9)$. But the opposite is more important to connect division of $8:(-9)$ with the fraction $-\frac{8}{9}$. You have to be systematic here, asking them [students] right questions to connect what they know in each step, going from $8:(-9)$ to $\frac{8}{-9}$ and than to $-\frac{8}{9}$.

Figure 1. Example of data analysis.

The following step was establishing the textbook utilisation type, specifically whether it was deliberate or non-deliberate use. Lastly, by summarising previous evaluations, I determined whether the teacher-textbook relationship was a participatory or non-participatory relationship.

\section{Results}

\section{Planning the lesson}

To establish how the teacher appropriates the textbook's content, I will first report how the textbook was used for planning a lesson.

When Ms D planned each lesson, she consulted the curriculum programme to establish the goal of the lesson and its expected outcomes. The next phase of planning included deciding on the introduction of new content, solved examples, and exercises. The textbook served as the first and fundamental curriculum resource used in this second phase. The process of examining the textbook content for the introduction of new content, solved examples, and exercises was guided by the teacher's lesson goals and outcomes. Ms D analysed each activity in the textbook and evaluated it in terms of the desired outcomes for the students. If the activity aligned with the outcomes, she took it into consideration and placed it in her lesson plan outline. For the forthcoming lessons, Ms D did not use other curricular resources, but she added that she consults the teacher guide or other textbooks if she does not like the textbook content at all or has no other ideas for the lessons. Then she analyses, evaluates, and adjusts, if necessary, every selected activity.

At the end of planning, Ms D evaluated her overall lesson plan and discarded any activities that were too similar. During the lesson planning process, she consulted her notes from the previous year to see if she had made any remarks about the enacted lesson. She explained that this helps her in lesson planning. This indicated use of learned adaptations.

For the forthcoming lessons, Ms D discarded the textbook approach suggested for the introduction of new content, claiming that the pedagogy behind the introduction was inadequate or wrong. Instead, she decided to introduce 
the new content on the basis of her previous experience with the topic or to adapt an activity from the teacher guide.

In the case of solved examples, Ms D adapted some from the textbook or created new ones based on what had been done in the previous phase, i.e., the introduction of new content. Ms D explained that she does not use the solved examples from the textbook as given because she does not see the point of solving what is already solved in the textbook. The exercises for the lessons came from the textbook. They were to be given as practice and as homework. Ms D analysed them and established that they were aligned with her goals.

In terms of lesson planning, Ms D not only plans her lessons on a daily basis but also has a monthly plan, so she can create lessons as a sequence. She explained that in this way she has a broader overview, so she is aware of the key points for each lesson, what needs to be 'done' in each lesson, and what she will use in the following lesson.

\section{$2 \quad$ Enacting the lesson}

Here I will compare the lessons observed in Ms D's classroom in terms of planning and enacting. The teacher planned and used offloading, adapting, and improvising in her lessons, but not to the same extent in every lesson. The teacher's mobilisation of the textbook, i.e., the degrees of appropriation and opportunities of mediation are shown in the lesson maps in Figure 2.

The lesson maps (Figure 2) show that the enacted lessons corresponded to Ms D's planned lessons, except for one occasion in which made an in-themoment decision, deviating from her lesson plan. Students were unable to remember how to divide whole numbers where the dividend is smaller than the divisor, so she stopped the current activity to remind them how to do it, using structured questioning in one example, and giving them several tasks for practice. This knowledge of division was necessary for the current topic. After the lesson, Ms D explained that her in-the-moment decision was necessary because the students were not able to proceed further with the given activity:

I had to insert that [...] I could see that the students didn't know or didn't remember from last year, so we devoted part of the lesson to the revision. Of course, I didn't manage to do everything I had planned, but this was very important [...] Yes, I couldn't go further. 


\section{Lesson 1}

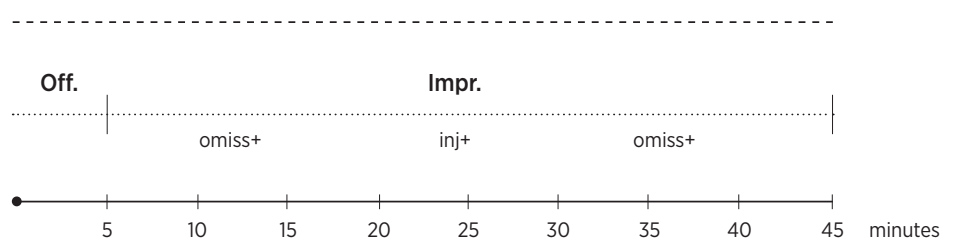

\section{Lesson 2}

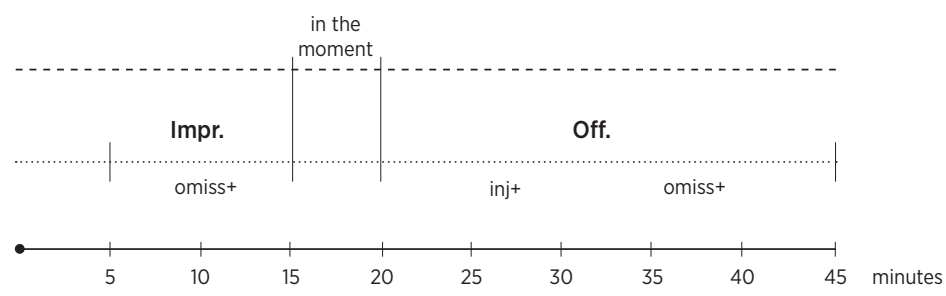

\section{Lesson 3}

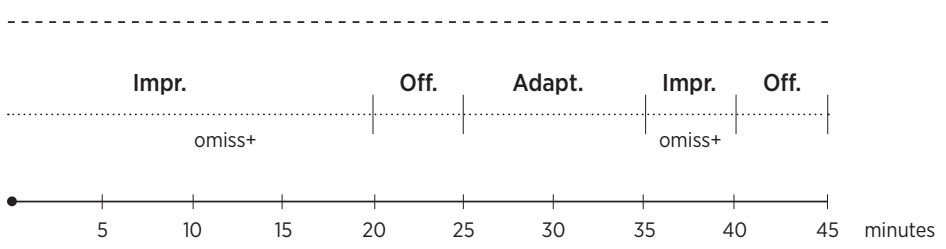

\section{Lesson 4}

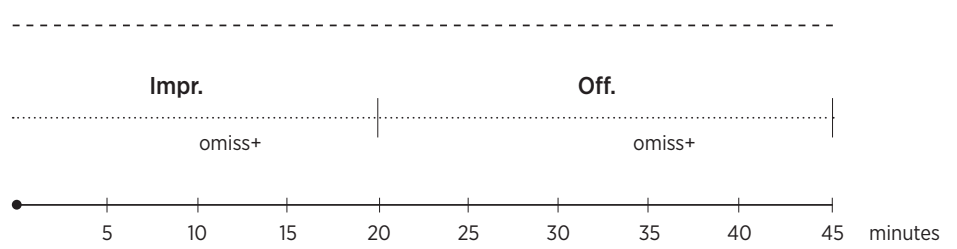

Legend:

inserted in the moment

planed

Off. = offloading

Adapt. $=$ adapting

Impr. = improvising

inj+ = robust injection

omiss $+=$ productive omission

Figure 2. Lesson maps. 
After each lesson, Ms D wrote comments for herself: what went well in the lesson, what she did not like in the lesson, and explained that she will consult these notes when she is preparing for the same lesson next year. This action shows the learned adaptations.

After the lessons I get new ideas, what could be done differently, so I write these comments in my notebook.

\section{Mobilisation of textbook content}

\section{Delineation of offloading}

In the observed lessons, Ms D offloaded almost all exercises, for practice and homework, from the textbook. In the interview, Ms D said she does not always follow the order of the exercises in the textbook if that order does not support the goals she sets when planning the lesson. She also explained that she attempts to use the textbook for practising when the exercises are aligned with her goals:

I do have to use the textbook sometimes [laughs] it's been bought and [...] I try to use the best of it. [...] In these lessons, the chosen textbook exercises have the purpose of reviewing and developing what was taught in the lesson.

All lessons I observed had the same title written on the blackboard as the lesson units in the textbook. Ms D explained that the title of the lesson in the textbook, definitions, and solved examples influence her lesson to some extent, and that she tries to keep them the same as in the textbook. According to Ms D, this helps students when they use the textbook for learning at home.

\section{Delineation of adapting}

In the lesson that dealt with the introduction of rational numbers, Ms D used a discovery learning activity to teach students the different types of rational numbers. The activity required students to determine whether every fraction could be written in the form of a decimal number. This activity was adapted from the textbook. The textbook gives an explanatory part on the classification of decimal numbers and then proceeds with the examples for each type of decimal number, i.e., exact and recurring numbers, respectively (Figure 3 ). 
Iz predhodnih primjera možemo videti da se racionalni brojevi zapisuju u obliku razlomaka, ali i u decimalnom obliku, kao decimalni brojevi.

U decimalnom zapisu racionalni su brojevi konačni decimalni brojevi ili beskonačni periodični decimalni brojevi. U sledječem primeru pokazat čemo kako se neki racionalni brojevi zapisuju kao konačni decimalni brojevi.

\section{Primjer 2.}

Racionalne brojeve zapišimo u obliku konačnih decimalnih brojeva.
a) $\frac{3}{100}$
b) $\frac{1}{2}$
c) $-\frac{3}{4}$
d) $\frac{-27}{3000}$
e) $\frac{3}{25}$

Rj. To možemo učiniti na dva načina: proširavanjem ili skrsčivanjem do decimalnog razlomka ili dijeljenjem brojnika i nazivnika.

a) $\frac{3}{100}$ decimalni je razlomak pa je $\frac{3}{100}=0.03$.

\section{Translation}

From the previous example we saw that rational numbers can be written in the fraction form, but also, in the form of decimal number. In the decimal form, rational numbers are either exact decimal numbers or recurring decimal numbers. In the following example, we will show how to write rational numbers as exact decimal numbers.

\section{Example 2.}

Write rational numbers in the form of exact decimal numbers.
a) $\frac{3}{100}$
b) $\frac{1}{2}$
c) $-\frac{3}{4}$
d) $\frac{-27}{3000}$
e) $\frac{3}{25}$

Solution. We can obtain this in two ways: by expanding or shortening until we obtain decimal fraction or by dividing numerator with denominator.

a) $\frac{3}{100}$ is decimal fraction so $\frac{3}{100}=0.03$.

Primjer 3.

Racionalne brojeve zapišimo u obliku bezkonačnih periodičnih decimalnih brojeva.
a) $\frac{5}{3}$
b) $\frac{3}{13}$
c) $\frac{11}{6}$
d) $\frac{7}{15}$

Rj. Učinit čemo to dijeljenjem brojnika i nazivnika.

\section{Translation}

\section{Example 3.}

Write rational numbers in the form of recurring decimal numbers.
a) $\frac{5}{3}$
b) $\frac{3}{13}$
c) $\frac{11}{6}$
d) $\frac{7}{15}$

Solution. We can obtain this by dividing numerator with denominator.

Figure 3. Original textbook content (translation by author).

From the teacher's perspective, the original activity contained too many cases for students to examine and had a significant flaw: dealing with each type of decimal number separately. Moreover, the teacher wanted the students to discover all forms of the decimal number to which fractions can be converted. Therefore, she decided to adapt those two solved examples into a discovery learning activity. Ms D made three worksheets, each containing three positive fractions, and distributed them in the classroom: one with a denominator with the prime factors 2 and/or 5; one with a denominator without the prime factors 
2 and 5; and the third with a denominator with a prime factor of 2 and/or 5 and another prime factor (Figure 4). She explained that students would meet two types of decimal numbers during the same activity.

\begin{tabular}{|c|c|c|}
\hline $\begin{array}{c}\text { Rational } \\
\text { number }\end{array}$ & $\begin{array}{c}\text { Decimal form } \\
\text { of rational number }\end{array}$ & $\begin{array}{c}\text { Factorization } \\
\text { of denominator }\end{array}$ \\
\hline$\frac{13}{50}$ & & \\
\hline$\frac{2}{9}$ & & \\
\hline$\frac{5}{6}$ & & \\
\hline
\end{tabular}

Figure 4. Example of adapting (translation by author).

Ms D set up pair work, followed by a class discussion about the types of decimal numbers discovered. Before the lesson, she explained why she modified the activity citing the students' abilities as the main reason:

I want them to discover this [points to the examples] by themselves. They [students] are really slow when they have to divide numbers ... and we only have 45 minutes [laugh]. So, three fractions are just enough.

After the lesson, Ms D concluded that she was correct not to use as many fractions as were given in the solved examples because her students experienced problems with division. She concluded that if she had used more fractions in the activity, there would not have been time for the whole class discussion, where they made a general conclusion, and the activity would not have been completed.

\section{Delineation of improvising}

In the lesson on the comparison of rational numbers, the teacher used a real rope that represented a number line and blue and red socks that had cards with various types of numbers. The blue socks represented wet socks, the red ones represented dry socks, and zero represented the point at which drying begins. The blue socks on the far left, with smaller numbers were wetter than the socks closer to zero. Similarly, the red socks placed on the far right were dryer than the socks on the right, closer to zero. Before the lesson, Ms D said that she wanted the students to get the feeling of 'what comparing numbers means' because she had observed in previous years that students do not fully understand what smaller or bigger means when 'rational numbers come into the picture.' The numbers Ms D used were a mixture of integers, decimal numbers, and fractions. The activity in the textbook 
also uses a number line as a model for comparison, but the textbook example has only four fractions and not mix of numbers from various number sets.

\section{Opportunities for mediation}

As described earlier, Ms D adapted some solved examples, and she created some herself, which means that several solved examples from the textbook were omitted. A comparison of the omitted examples with those that Ms D created shows that the omitted examples do not contain knowledge critical for students' understanding. Ms D also omitted some exercises. The textbook contains many similar exercises with the same pedagogy behind them; thus, those omitted exercises can be seen as benign in terms of the students' knowledge. Therefore, the omitted exercises and worked examples can be considered to be productive omissions.

Ms D made several injections of mathematical content that is not prescribed by the curriculum or contained in the textbook for this grade level. She introduced standard mathematical notation for rational numbers in the form $\frac{a}{b}$ and mathematical notation for the set of rational numbers $Q=\left\{\frac{a}{b}: a \in Z\right.$, $b \in N\}$. These notations are not required by curriculum standards; however, she brought them into the lesson explaining 'It will not hurt them [students] to know a little bit more'. Ms D explained that she injects content that is not in the textbook or curriculum when she thinks this content is important for the students:

I study the curriculum programme for the upper grades and the lower grades to see connections with was learnt, and what will be learnt $[\ldots]$ So I estimate how important something is for them [students].... Given my experience also, I know what will be important in the next grade, and some things, which I consider important, are not in the textbook.

The teacher introduced both types of recurring decimal numbers, with pure and mixed periods, even though these types of decimal numbers are part of the Grade Eight curriculum in the topic of real numbers. However, in the interview, the teacher emphasised that this is a good place for the introduction of those rational numbers, because students are examining/discovering whether all fractions can be written in the form of decimal numbers and they tend to notice these differences. The introduction of new content could create opportunities to enhance students' learning; therefore, these injections can be regarded as robust injections of mathematical content. 


\section{Textbook utilisation and lesson design}

From the findings in the previous sections, Ms D's lesson designing for the four observed lessons can be depicted in the following diagram (Figure 5):

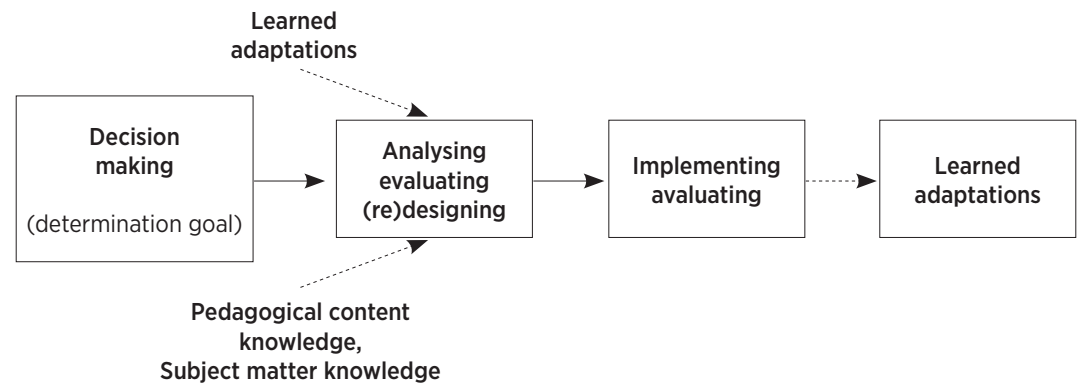

Figure 5. Ms D’s lesson design process.

The diagram shows the trajectory or pathway of Ms D's lesson design process. All the obtained results show that the teacher engaged in long considerations of textbook content; therefore, her utilisation of the textbook can be characterised as deliberate. The relationship she has with the textbook is participatory, because both the teacher's characteristics and the textbook influenced the outcomes in the classroom.

\section{Discussion and conclusion}

To determine how the teacher appropriated the textbook content, this study used Brown's (2009) scale of offloading, adapting, and improvising. The scale describes the different contributions of instructional resources and distributions of design responsibility. Degrees of appropriation were identified using interviews and on-site observations, but it was the information obtained from the teacher before and after lesson enactment that explained why the textbook is used in such a way and helped in determining the teacher-textbook relationship. Together, those data provided evidence for the teacher's design capacity.

The teacher in this study used offloading, adapting the textbook content, and improvising to varying degrees in her teaching, being aware of the affordances and constraints which the textbook has for her teaching practice. When the teacher offloaded a lesson or part of a lesson, she did so because her goals were aligned with the textbook goals and because she recognised the pedagogical benefit of such offloading. Similarly, Brown and Edelson (2003) 
showed that teachers in their study offloaded textbook content not because of their discomfort with the subject matter, but because of their ability to recognise the pedagogical benefit of relying on the materials to accomplish a particular goal. The teacher, Ms D, also adapted some content from the textbook, changing it to better suit her intentions. Related to this issue, Davis and Krajcik (2005, p. 9) point out that 'we should not expect a teacher to invent a new strategy for every new topic.' Therefore, offloading and adapting curriculum materials are justifiable means for achieving the desired teaching outcome. When improvising, Ms D occasionally posed problems that suited her lesson goals more than the problems or tasks given in the textbook. Moreover, she never used the solved examples from the textbooks. This result can relate to the recent study by Klinshtern, Koichu, and Berman (2015), who detected that around 50\% of their surveyed teachers see themselves as problem posers. The main reason the teachers gave for posing their 'own' problems was that their problems were somehow different from those in the available resources; for instance, students have not encountered those type problems yet, and the teacher's problems fulfilled teaching needs. All these reasons were evident in Ms D's explanations.

The results of the study show that during lesson planning and lesson enacting, the teacher used the textbook in a deliberate way. Her utilisation of it was conscious, thoughtful, and purposeful. In that utilisation, she made no critical omissions or distractive injections. The interplay of improvising, adapting, and offloading throughout the lessons and the participatory relationship with the textbook shifts the teacher from a mediator of the curriculum to a designer of the teaching. The teacher's design capacity was evident from the robust injections of content that enhanced opportunities for learning, and productive omissions of the textbook content. Moreover, she maintained the focus on the mathematical point during instruction and perceived students' understanding of the mathematical points during the enactment, which constitutes additional evidence for establishing a teacher's pedagogical design capacity, according to Remillard (2016). The teacher in this study took care of students' understanding during the lesson. At one point, she made an in-the-moment decision deviating from her lesson plan in order to strengthen students' understanding. When this understanding was achieved, Ms D steered the lesson back to the planned mathematical pathway. However, she also considered the students' understanding before the lesson, foreseeing possible problems and adapting the activity to the students' abilities. Even though student learning outcomes and students' perspective of learning processes are significant measures of PDC, in this research design, I based the conclusions on different, but also relevant resources. All the above evidence indicates that the teacher was able to perceive and mobilise existing resources in a meaningful way. 
One of the key aspects of a teacher's PDC in this study is being aware of affordances and constraints of the textbook, being able to mobilise it effectively and appropriately. The teacher detected these affordances and constraints through the processes she employs when she prepares for the lesson: analysing content/activities and evaluating them in terms of desired outcomes and students' abilities.

The finding of this study could be expressed in relation to the broader public. The mathematics teacher's awareness of what a resource offers for teaching practice and what constraints could be encountered on this journey are essential in terms of the teacher's design capacity. This awareness is the result of the interplay between pedagogical content knowledge, subject matter knowledge, learned adaptations, and the evaluation of implemented activity after lesson enactment, but also the result of the teacher's continuous professional development. The first influence the analysis, evaluation and (re)designing of activities during lesson planning, while the latter accumulate in the form of learned adaptation. Moreover, this awareness can influence the use of the textbook in a deliberate, conscious way and can help the teacher to establish a participatory relationship with the textbook. This, in turn, improves and upgrades the design capacity related to the resource. It would be interesting to replicate the research with a teacher that is less reflective, or not so effective.

If PDC is the ability 'to perceive and mobilise', the teacher must be able to estimate the outcome of an activity in relation to his students, to change it if necessary and use it for a specific purpose. Huizinga (2014) calls the knowledge to analyse, design, and evaluate a task and to overcome its challenges 'curriculum design expertise'. Therefore, an essential component of a teacher's PDC is selecting and analysing curriculum resources and evaluating the outcome of their use. However, this expertise cannot be realised without a good knowledge of the students, i.e., their development level, pre-existing knowledge, skills, intuitive beliefs and attitudes, and their state of mind. The teacher must be sensitive to the process of meaning construction of his students, their construction of knowledge, learning process, potential obstacles, and any signs of misunderstanding or struggling for understanding. Davis and Krajcik (2005) describe PDC as vital for a teacher's involvement in the practice of teaching. Having a high level of PDC enables a teacher to become an agent in curriculum design and enactment, instead of a person who simply implements a set of given curriculum materials. 


\section{Acknowledgements}

I would like to thank the anonymous reviewers who made many valuable suggestions which improved the study described in this paper.

\section{References}

Ball, D. L., \& Cohen, D. K. (1996). Reform by the book: What is or might be the role of curriculum materials in teacher learning and instructional reform? Educational Researcher, 25(9), 6-14.

Brown, M. (2009). The teacher-tool relationship: Theorizing the design and use of curriculum materials. In J. T. Remillard, B. A. Herbel-Eisenmann, \& G. M. Lloyd (Eds.), Mathematics teachers at work: Connecting curriculum materials and classroom instruction (pp. 17-36). New York, NY: Routledge.

Brown, M., \& Edelson, D. C. (2003). Teaching as design: Can we better understand the ways in which teachers use materials so we can better design materials to support their changes in practice? Evanston, IL: The Center for Learning Technologies in Urban Schools.

Clandinin, D. J., \& Connelly, F. M. (1992). Teacher as curriculum maker. In P. W. Jackson (Ed.), Handbook of research on curriculum (pp. 363-401). New York, NY: Macmillan.

Choppin, J. (2011). Learned adaptations: Teachers' understanding and use of curriculum resources. Journal of Mathematics Teacher Education, 14(5), 331-353.

Davis, E. A., \& Krajcik, J. S. (2005). Designing educative curriculum materials to promote teacher learning. Educational Researcher, 34(3), 3-14.

Fan, L., Zhu, Y., \& Miao, Z. (2013). Textbook research in mathematics education: Development status and directions. ZDM-The International Journal on Mathematics Education, 45(5), 633-646.

Gueudet, G., Pepin, B., \& Trouche, L. (2013). Collective work with resources: An essential dimension for teacher documentation. ZDM: International Journal on Mathematics Education, 45(7), 1003-1016. Glasnović Gracin, D. (2011). Requirements in mathematics textbooks and PISA assessment (Doctoral dissertation). Klagenfurt: University of Klagenfurt.

Glasnović Gracin, D., \& Jukić Matić, Lj. (2016). The role of mathematics textbooks in lower secondary education in Croatia: An empirical study. The Mathematics Educator, 16(2), 29-56.

Goetz, J. P., \& Le Compte M. D. (1984). Ethnography and qualitative design in educational research. London, UK: Academic Press.

Huizinga, T. (2014). Developing curriculum design expertise through teacher design teams (Doctoral dissertation). Enschede: University of Twente. doi:10.3990/1.9789036537698

Johansson, M. (2006). Teaching mathematics with textbooks. A classroom and curricular perspective (Doctoral dissertation). Luleå: Luleå University of Technology.

Jukić Matić, L., \& Glasnović Gracin, D. (2015). How Croatian mathematics teachers organize their teaching: Differences according to the initial education. In Z. Kolar-Begović, R. Kolar-Šuper, \& I. Đurđević Babić (Eds.), Higher goals in mathematics education, (pp. 303-317). Osijek: Element. 
Klinshtern, M., Koichu, B., \& Berman, A. (2015). What do high school teachers mean by saying 'I pose my own problems'? In F. M. Singer, N. Ellertonm, \& J. Cai (Eds.), Problem posing: From research to effective practice (pp. 449-467). New York, NY: Springer.

Kvale, S. (1996). InterViews: An introduction to qualitative research interviewing. London, UK: Sage Publication.

Leshota, M. (2015). The relationship between textbook affordances and mathematics' teachers' pedagogical design capacity (Doctoral dissertation). Johannesburg: University of the Witwatersrand.

Retrieved from http://wiredspace.wits.ac.za/handle/10539/18211

Love, E., \& Pimm, D. (1996). This is so: A text on texts. In A. J. Bishop, K. Clements, C. Keitel, J. Kilpatrick, \& C. Laborde (Eds.), International handbook of mathematics education (Vol. 1, pp. 371-409). Dordrecht: Kluwer Academic Publishers.

Patton, M. Q. (2002). Qualitative research and evaluation methods (3rd ed.). Thousand Oaks, CA: Sage Publications.

Pepin, B. (2015). Enhancing mathematics/STEM education: a 'resourceful' approach. Inaugural lecture, 27 November 2015. Eindhoven: Technische Universiteit Eindhoven.

Pepin, B., Gueudet, G., \& Trouche, L. (2013). Re-sourcing teachers' work and interactions: a collective perspective on resources, their use and transformation. ZDM-The International Journal on Mathematics Education, 45(7), 929-943.

Pepin, B., \& Haggarty, L. (2001). Mathematics textbooks and their use in English, French and German classrooms: A way to understand teaching and learning cultures. ZDM - The International Journal on Mathematics Education, 33(5), 158-175.

Rabardel, P. (2002). People and technology: A cognitive approach to contemporary instruments. Paris:

Université Paris. Retrieved from https://hal.archives-ouvertes.fr/hal-01020705

Remillard, J. T. (2005). Examining key concepts in research on teachers' use of mathematics curricula. Review of Educational Research, 75(2), 211-246.

Remillard, J. (2016). Teachers' design decisions and the role of instructional resources. International Congress on Mathematics Education. Hamburg: Germany, doi:10.1314o/RG.2.1.2491.6726

Shield, M. J., \& Dole, S. (2013). Assessing the potential of mathematics textbooks to promote deep learning. Educational Studies in Mathematics, 82(2), 183-199.

Thomson, S., \& Fleming, N. (2004). Summing it up: Mathematics achievement in Australian schools in TIMSS 2002. Melbourne: Australian Council for Educational Research.

Valverde, G. A., Bianchi, L. J., Wolfe, R. G., Schmidt, W. H., \& Houang, R. T. (2002). According to the book. Using TIMSS to investigate the translation of policy into practice through the world of textbooks.

Dordrecht: Kluwer Academic Publishers.

Wartofsky, M. W. (1979). Models: Representation and the scientific understanding. Dordrecht: Reidel. 


\section{Biographical note}

LJerka Jukić Matić, PhD, is Assistant Professor at Department of Mathematics, Josip Juraj Strossmayer University of Osijek, Croatia. Her current research interest includes education of pre-service mathematics teachers, mathematics teacher's work with curriculum resources and professional development of in-service and pre-service teachers. 